Article

\title{
Applying a Delphi-Type Approach to Estimate the Adaptation Cost on Agriculture to Climate Change in Cyprus
}

\author{
Marinos Markou ${ }^{1}\left(\mathbb{D}\right.$, Anastasios Michailidis $^{2, *}{ }^{(\mathbb{C}}$, Efstratios Loizou $^{3}{ }^{(D)}$, Stefanos A. Nastis ${ }^{2}(\mathbb{D}$,

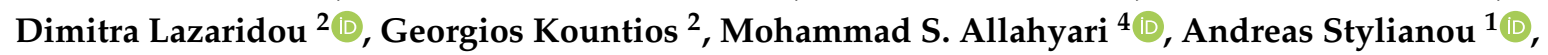 \\ George Papadavid ${ }^{1}$ and Konstadinos Mattas ${ }^{2}$ \\ 1 Agricultural Research Institute, Nicosia 1516, Cyprus; markou@ari.gov.cy (M.M.); \\ a.stylianou@ari.gov.cy (A.S.); papadavid@ari.gov.cy (G.P.) \\ 2 Department of Agricultural Economics, Aristotle University of Thessaloniki, 54124 Thessaloniki, Greece; \\ snastis@auth.gr (S.A.N.); dimitral@for.auth.gr (D.L.); gkountios@gmail.com (G.K.); mattas@auth.gr (K.M.) \\ 3 Department of Regional Development and Cross Border Studies, University of Western Macedonia, \\ 50100 Kozani, Greece; eloizou@uowm.gr \\ 4 Department of Agricultural Management, Rasht Branch, Islamic Azad University, Rasht 41335-3516, Iran; \\ allahyari@iaurasht.ac.ir \\ * Correspondence: tassosm@auth.gr
}

Received: 12 April 2020; Accepted: 19 May 2020; Published: 21 May 2020

\begin{abstract}
Agriculture is highly dependent on climate change, and Cyprus especially is experiencing its impacts on agricultural production to a greater extent, mainly due to its geographical location. The adaptation of farming to the effects of global climate change may lead to the maximization of agricultural production, which is an important and desirable improvement. The main aim of this paper is to rank and quantify the impacts of climate change on the agricultural sector of Cyprus, through a multi-round Delphi survey seeking a consensus agreement in a group of experts. A multidisciplinary group of 20 experts stated their willingness-to-pay for various impacts of climate change. By applying this method, the individual impacts of climate change on crop production and water resources were brought into the modeling effort on equal footing with cost values. The final cost impact estimate represents the total estimated cost of climate change in the agricultural sector. According to the results, this cost reaches EUR 25.08 million annually for the agricultural sector, and EUR 366.48 million for the whole country. Therefore, it is expected that in the seven-year programming period 2014-2020 the total cost of climate change on agriculture ranges from EUR 176 to EUR 2565 million. The most significant impacts are due to the increasing level of $\mathrm{CO}_{2}$ in the atmosphere and the burden of biodiversity and ecosystems.
\end{abstract}

Keywords: agriculture; climate change; Delphi method; impacts; water resources; willingness-to-pay

\section{Introduction}

The climate of Cyprus, as a typical Mediterranean country, is semi-arid with mild, wet winters and hot, dry summers. According to the literature [1], the mean daily minimum temperatures during winter and summer are $5{ }^{\circ} \mathrm{C}$ and $36^{\circ} \mathrm{C}$, respectively, with a slight upward trend every year. Cyprus has limited water resources and the highest Water Exploitation Index (45\%) in the European Union [2]. The Water Exploitation Index is an indicator that illustrates if a country is water stressed or not. According to the literature [3], the threatening level is $20 \%$, distinguishing a water non-stressed area from a stressed one. The combination of limited availability, especially during years of excessive drought, and excess demand for water among competing uses is the principal cause of water scarcity. 
Drought is a very frequently occurring condition that mainly occurs due to the large inter-annual decrease in precipitation. According to the literature [4], during the last 40 years, drought incidents have increased not only in frequency (every two or three years) but also in duration and magnitude.

During the decade 1990-2001, Cyprus was under high pressure mainly due to severe droughts occurring on the island, with important negative impacts on the ecosystems. According to the literature [5], the satisfactory irrigation of forests has been negatively impacted by the reduced rainfall, which has significant implications:

- reduced inflows to dams and wetlands

- reduced water for irrigation

- unsatisfactory recharge of the aquifers

- reduced domestic water supply risking the quality of life and citizens' sanitation

- adverse effects on biodiversity

- social, economic, and environmental adverse effects

- threat of fires due to drylands

- uncontrolled fires and environmental disasters

Climate and agriculture are usually related via a procedure of two-way impacts [6]. Since time immemorial climate (at a local, regional and global scale) has been influenced and shaped by agricultural activities, and vice versa $[7,8]$. The available soil moisture and the levels of heat transfer rising between the ground and the atmosphere are determined by plant cover rate due to irrigation. Therefore, agriculture is significantly affected by climate change while the global climate has been also affected by agriculture, as (in its broadest sense, including livestock production that emits some of the greenhouse gases) it is a high-contributing activity to the acceleration of climate change. It is estimated that agriculture generates $20 \%$ of carbon dioxide $\left(\mathrm{CO}_{2}\right)$ worldwide [9], and it contributes about $42 \%$ of the increasing $\mathrm{N}_{2} \mathrm{O}$ emission into the atmosphere [10], as well as more than half of the world's emissions of $\mathrm{CH}_{4}$ [11,12]. According to [13], a combination of many human activities or natural changes directly or indirectly affects climate change, which is also affecting the sustainable agricultural development in a positive or negative way.

Climate change is a threat to agricultural activity, but according to [14] it may be also a significant challenge, as agriculture is among the economic sectors that are most sensitive to climate change, and thus any action on the direction of climate change delay could be linked with high potential and desirable improvements. Global food production, food prices, welfare, and global GDP are predicted to be negatively influenced by climate change, while the estimated welfare losses will be significant $[11,15]$.

During the 1960s, according to [16], the management of water resources became particularly complicated and difficult for both irrigation and domestic use. The lack of public water infrastructure and the ever-increasing water requirements were the main reasons for this problematic situation. On the other hand, among the main governmental priorities was the stable supply of high-quality water, in order for food security and socio-economic development not to be affected by water scarcity [13]. Considering that agriculture was the main pillar of the national economy, responsible for more than $20 \%$ (before the year 1980) of the national gross domestic product (GDP), any action towards agricultural productivity was an important and desirable improvement. Nowadays, the national economy has changed dramatically as the country becomes service-oriented and -dominated. Although the contribution of agriculture to the whole national economy is rapidly decreasing, accounting for less than $2 \%$ of GDP and $7 \%$ of the total workforce (year 2014), agriculture remains the dominant water consumer, using more than $60 \%$ of total water supply [17]. During the last five decades, the government has constructed many dams and water reservoirs in order to store as much freshwater as possible. According to [18], the national water storage capacity has multiplied 50 times, increasing from 6 million cubic meters in 1960 to 327 million cubic meters in 2009. 
According to [19], the productivity of the agricultural sector in Cyprus and the resulting productivity of the national economy have been both determined by weather conditions and climate change. Climate is one of the most important factors influencing farming systems and farm incomes. The establishment of the quantity and quality of farming output depends on the ideal level of harmonization between the characteristics of harvest species and the surrounding climate and atmosphere conditions. It is obvious that each action of rural activity is influenced by climate, requiring the persistent adjustment of farming to a wide scope of elements. Hence, to permit the support of satisfactory standards of future farm production, the adjustment of farming to the impacts that represent straightforward environmental change (i.e., global warming, soil salinization, an increase of $\mathrm{CO}_{2}$ concentration, and drought) ought to be focused on.

This paper mainly aims to distinguish, rank, and evaluate the cost of climate change on Cypriot agriculture, using primary data from a structural survey and utilizing the already existing knowledge and information of a group of experts. In particular, 20 experts engaging in climate change research (academics, staff scientists, policy makers and large farmers) have been selected via a specific selection procedure, described in detail in the next section. A modified Delphi method has been employed, including several rounds, interactive procedures, and quantification of the responses. According to [20-22], willingness-to-pay (WTP) is a widely use technique that allows better valuation of non-market goods or services than any another methodology. Thus, repeated WTP values have also been included in the survey of experts, in order to quantify climate change impacts and the transformation of ecosystem and environmental services [23]. The WTP technique asks people directly to state how much they would be willing to pay for a non-market good or service, and belongs to the group of "stated preference" methods, rather than inferring values from actual choices, as do the "revealed preference" methods. The WTP approach has been widely criticized, mainly because it is based on hypothetical and not observed behavior. However, the WTP approach belongs among a very few techniques allowing the valuation of non-market goods or services. In this paper, the WTP approach has been used additionally to support the Delphi methodology in assessing the adaptation cost of Cypriot agriculture to climate change, and in quantifying the impacts of climate change on agriculture. From a methodological viewpoint, this paper offers a novel research framework to estimate the adaptation cost of any country's agriculture to climate change. From a practical viewpoint, this paper employs a methodological mix of both qualitative and quantitative approaches, to value several impacts of climate change on agriculture, and to adapt appropriate policy measures to avoid even higher costs in the future.

\section{Methodology}

The conventional Delphi approach was first described by [24]. Today, it is a well-established and widely used forecasting process framework based on the results of multiple rounds of questionnaires sent to a panel of experts [25]. The Delphi consensus technique has been employed by the research community as a solving tool for a wide range of problems, utilizing experts' viewpoints and knowledge. According to [26], the Delphi approach has been applied most commonly in natural and environmental resources management issues. However, climate change issues have been also analyzed with the Delphi approach, but only in three research papers [27-29].

In this paper, a modified Delphi-type methodology has been developed using experts' WTP values in order to extract quantified results. Although a traditional survey could be used with a group of experts or stakeholders to gather primary data concerning climate change impacts, the employment of a modified Delphi approach has been judged to be a stronger methodology. Among the novel approaches falling between qualitative and quantitative, the "choice experiments", the "simulated client techniques" and the "nominal group techniques" have been also mentioned [30]. However, according to the same source, all these limited dependent variable approaches contain two important inherent weaknesses: (a) discrete choices provide less information as they accept only ordinal data, and (b) the mean values and the variances on the abeyant scale cannot be detached, and they are totally confused. 
According to the report of Okoli et al. [31], among others, the following reasons justify the suitability of the selected quantitative Delphi methodology to the paper's aims:

- $\quad$ there is no need for a physical meeting of experts

- there is no requirement for a large number of experts, but for a small number of the most specialized ones

- it's an appropriate method to rank climate change impacts

- it can be used additionally to evaluate climate change impacts (using WTP values)

- a deeper understanding of the complex research question has been allowed

- it's a flexible method to follow-up interviews

- it's a compatible method for complex study questions that require deep knowledge

- it's a compatible method for compound concerns that need practical experience from experts, who deeply understand several dimensions of climate change (economic, environmental, agronomical, social and political).

At the beginning, invitation letters were sent to the selected experts asking them to participate in the surveys and complete the requested steps. In the present study, the employed methodology involves three separate stages. First, an open-type survey tool has been initially e-mailed to experts' accounts, asking for their general views and insights into narrowing down the list to the most important climate change impacts. Following this, based on the results of the previous stage, a modified "ranking-type" version of the survey has been developed and e-mailed to the same experts [32]. Finally, a closed-type survey has been sent to the group of experts to estimate the most important climate change impacts using WTP values.

According to [33], any Delphi panel must consist of 15-60 experts. To ensure that the selected experts meet some pre-defined desirable characteristics, purposive sampling was used in a larger group of potential experts [34]. Eventually, the panel in this research included 20 selected experts engaged in climate change research (academics, staff scientists, policy makers and large farmers). Panel members' selection was heterogeneous, given that the literature demonstrates that decision-making groups perform better when they are heterogenous [35]. This panel of experts has been designed and manned in a very meticulous way, in order to represent the wide number of stakeholders and to increase the reliability and validity of quality indicators [36]. Figure 1 presents the employed general multi-step selection procedure of panel experts based on the guidelines of the literature [37-41].

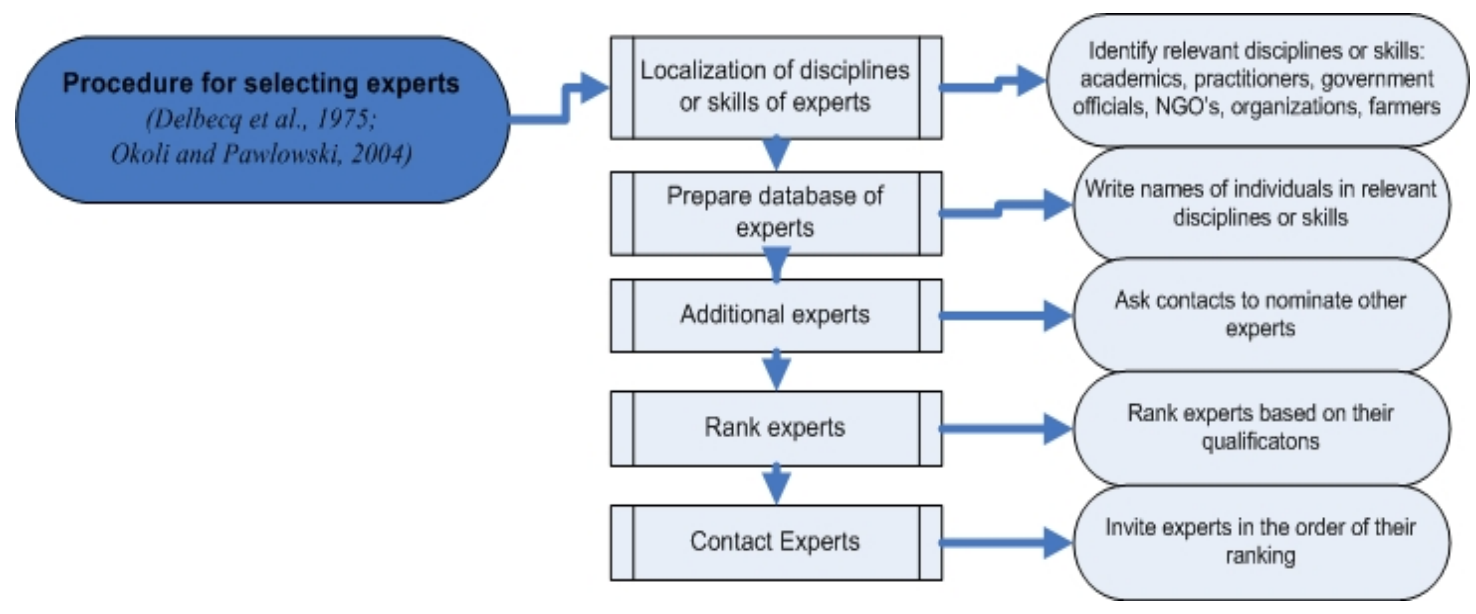

Figure 1. Procedure for selecting experts.

The selection procedure of experts was followed by the first step of data collection, in order to address the research aims. Each expert was asked initially to list at least six important impacts of climate change on Cypriot agriculture. Based on the results of this first stage, a list of grouped climate 
change impacts was generated, merging alike or similar responses via a creative process. In the second stage this generated list was sent to the heterogeneous group of experts, asking them to validate our interpretation of their responses. In the third stage each expert was asked to rank hierarchically the climate change impacts on the basis of their effects on the primary sector. In the final stage, each expert was asked to recommend a hypothetical maximum WTP amount to avoid these climate impacts (one by one). Each expert was asked to mention one indicative amount per climate change impact, without having any upper or lower limit. The only information they received was the average price and standard deviation of the balances per impact category. They did not have the ability to directly affect the prices of the rest, nor did they know the names of the panel members. They were asked to change their choices (they were free to accept or not) in order to decrease the standard deviation of the responses (consensus condition). The consensus condition in this paper was satisfied when the standard deviation of all expert's WTP values for all climate change impacts did not exceed $30 \%$ of the mean WTP value of the impacts. The final step was repeated several times (three in this case) until the consensus condition was met. In the cases of unsatisfied conditions, each expert was asked to recommend an improved hypothetical maximum WTP value closer to the respective mean WTP value. Figure 2 presents a flow chart of the data collection process.

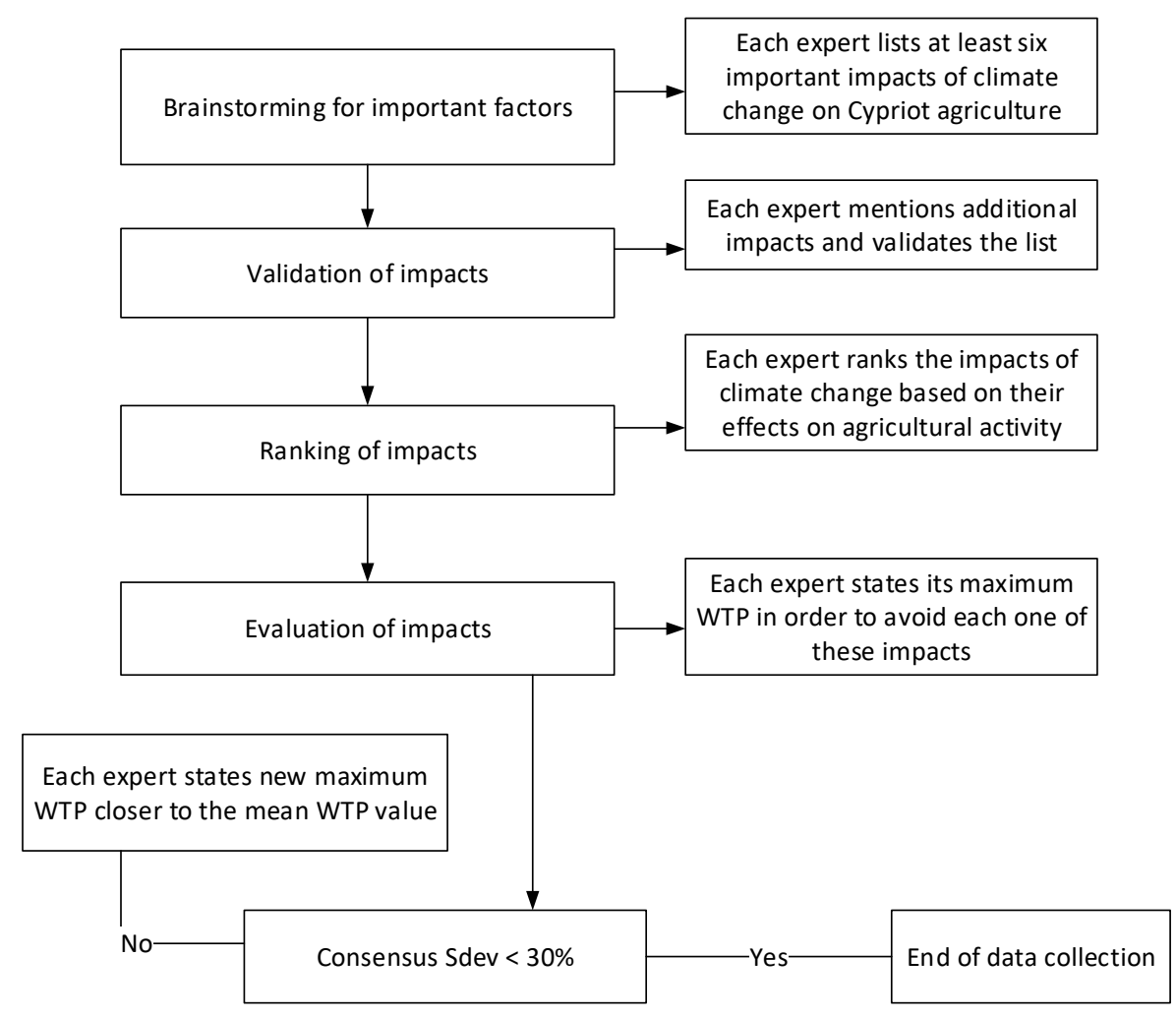

Figure 2. Data collection process.

\section{Results}

Following the research plan, the group of experts participated with remarkable consistency, replying in a satisfactory way to all requested surveys. The experts were requested, during these repeating rounds, to change their offers in order to obtain a degree of consensus. In that way, the standard deviation of all experts' WTP values continuously decreased until the satisfaction of the consensus. As already mentioned, the consensus condition was not able to be met during the first and second round. However, finally in the third round, consensus among the expert panel was gained. Figure 3 presents graphically the satisfaction of consensus concept after three rounds using the red line 
limit. It is obvious that during the third round the mean standard deviation of all impacts was less than $30 \%$ of the mean WTP value of the impacts (located to the left side of the red line).

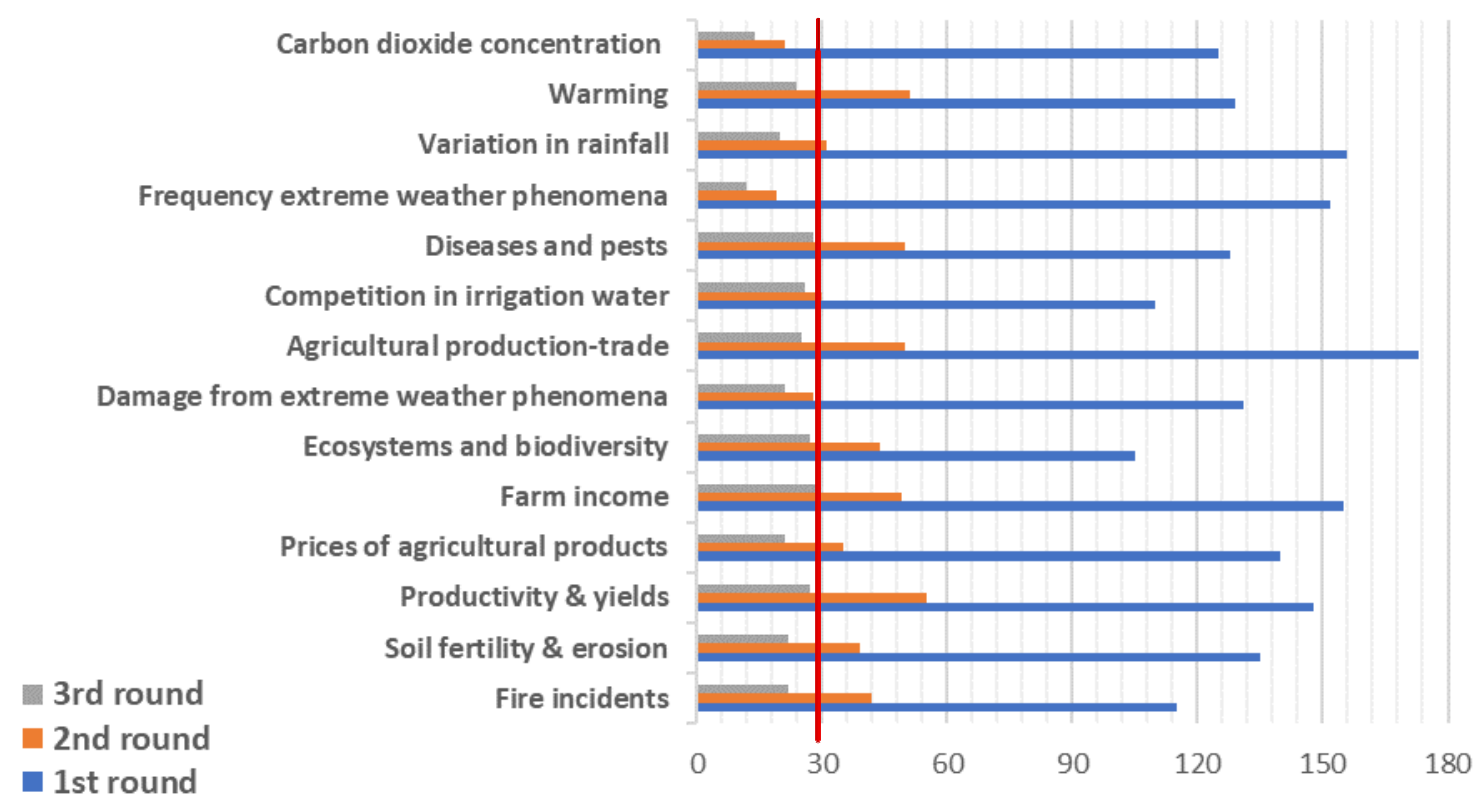

Figure 3. Satisfaction of consensus concept (after 3 rounds).

Table 1 presents the experts' rating results for each one of the climate change impacts during the first, second and third rounds, respectively. It summarizes the experts' valuation of statements, expressed in monetary units of EUR maximum, EUR minimum and EUR mean annual Willingness-To-Pay, as assessed using the hypothetical or dependent valuation, including the respective standard deviations. According to the first round's results, in almost all climate change impacts (except increased fire incidents) the minimum WTP value was zero, while the calculated mean values ranged from EUR 8.47 (diversification of agricultural production and agricultural trade) to EUR 33.16 (increasing of $\mathrm{CO}_{2}$ concentration). These amounts represent the initial WTP of the panel of experts in order to avoid the climate change impacts on Cypriot agriculture. A typical expert (represented by the mean values of all experts) estimates the negative impacts of climate changes to agriculture to equal EUR 299.93 (Sum of average values of all impacts). Both minimum and maximum values, in all rounds, have been calculated using mean values and standard deviations. Particularly, the maximum values were calculated by adding the mean values and the respective standard deviations. On the other hand, the minimum values were calculated as the differences between mean values and the respective standard deviations. In case of negative differences, the respective minimum values have all been set to zero. Thus, extreme values of climate change impacts are side-stepped, and the probability of calculating extreme positive or extreme negative WTP amounts is restricted, achieving more representative evaluation. During the second round the average WTP values ranged between EUR 8.97 (diversification of agricultural production and agricultural trade) and EUR 33.08 (increasing of $\mathrm{CO}_{2}$ concentration), while during the third round the average WTP values ranged from EUR 9.50 to EUR 32.66. It is worth mentioning the average WTP values from one round to another were significantly changed. On the other hand, both maximum and minimum values have changed, almost approaching the respective average values, while the respective standard deviations have decreased. 
Table 1. Rating results for the Delphi first, second and third round's Willingness-To-Pay values (EUR maximum, EUR mean and EUR minimum).

\begin{tabular}{|c|c|c|c|c|c|c|c|c|c|c|c|c|}
\hline \multirow{2}{*}{$\begin{array}{l}\text { Impacts of } \\
\text { Climate } \\
\text { Change }\end{array}$} & \multicolumn{4}{|c|}{ First Round's Results } & \multicolumn{4}{|c|}{ Second Round's Results } & \multicolumn{4}{|c|}{ Third Round's Results } \\
\hline & $\operatorname{Max}$ & Mean & Min & $\begin{array}{l}\text { Standard } \\
\text { Deviation }\end{array}$ & Max & Mean & Min & $\begin{array}{l}\text { Standard } \\
\text { Deviation }\end{array}$ & Max & Mean & Min & $\begin{array}{l}\text { Standard } \\
\text { Deviation }\end{array}$ \\
\hline $\mathrm{I} 2$ & 60.55 & 30.00 & 0.00 & 30.55 & 46.11 & 31.00 & 17.89 & 14.11 & 39.34 & 31.11 & 22.88 & 8.23 \\
\hline I3 & 59.68 & 29.15 & 1.38 & 29.15 & 35.99 & 25.56 & 15.13 & 10.43 & 34.47 & 27.52 & 20.56 & 6.96 \\
\hline $\mathrm{I} 4$ & 54.82 & 24.42 & 0.00 & 30.61 & 38.92 & 25.57 & 12.21 & 13.36 & 32.19 & 25.01 & 17.82 & 7.19 \\
\hline I7 & 49.01 & 23.79 & 0.00 & 25.24 & 34.18 & 26.42 & 18.65 & 7.77 & 27.13 & 24.41 & 21.68 & 2.73 \\
\hline I8 & 48.32 & 21.25 & 0.00 & 27.26 & 29.14 & 22.72 & 16.30 & 6.42 & 26.75 & 22.00 & 17.24 & 4.76 \\
\hline I9 & 48.72 & 21.05 & 0.00 & 27.67 & 27.32 & 20.03 & 12.73 & 7.30 & 25.51 & 20.84 & 16.17 & 4.67 \\
\hline I10 & 44.30 & 18.42 & 0.00 & 25.88 & 25.13 & 18.55 & 11.97 & 6.58 & 22.17 & 18.66 & 15.14 & 3.52 \\
\hline I11 & 44.66 & 17.47 & 0.00 & 27.19 & 24.55 & 18.66 & 12.77 & 5.89 & 22.48 & 18.46 & 14.44 & 4.02 \\
\hline I12 & 40.36 & 15.79 & 0.00 & 24.57 & 29.18 & 19.31 & 9.44 & 9.87 & 21.71 & 16.82 & 11.93 & 4.89 \\
\hline \multicolumn{13}{|c|}{ Index } \\
\hline I1. Increasin & of $\mathrm{CO}_{2}$ & oncent & ion & & & & & \multicolumn{5}{|c|}{$\begin{array}{l}\text { I8. Increased spending on tackling the cost of } \\
\text { irrigation water, appropriate propagation material, } \\
\text { special fertilizers and damage from extreme } \\
\text { weather phenomena }\end{array}$} \\
\hline \multicolumn{7}{|c|}{$\begin{array}{l}\text { I2. Burden on the environment, ecosystems and of biodiversity (loss } \\
\text { of native species) }\end{array}$} & & \multicolumn{5}{|c|}{ I9. Burden of soil fertility and erosion } \\
\hline \multicolumn{8}{|c|}{ I3. Increased fire incidents } & \multirow{4}{*}{\multicolumn{5}{|c|}{$\begin{array}{l}\text { I10. Increase in price of agricultural } \mathrm{p} \\
\text { I11. Variation in rainfall } \\
\text { I12. Reduction of farm income } \\
\text { I13. Change in productivity and yield }\end{array}$}} \\
\hline I4. Warming & & & & & & & & & & & & \\
\hline I5. Increasec & occurre & cee of di & eases a & pests & & & & & & & & \\
\hline I6. Increasec & frequen & $y$ of ext & eme w & ther events & & & & & & & & \\
\hline \multicolumn{8}{|c|}{ I7. Intensity of competition in water use in agriculture } & \multicolumn{5}{|c|}{$\begin{array}{l}\text { I14. Diversification of agricultural production and } \\
\text { agricultural trade }\end{array}$} \\
\hline
\end{tabular}

The following Figures 4-6 illustrate the quantification procedure for all groups of climate change impacts on the agriculture of Cyprus, using cobweb diagrams of the average WTP values given by experts. Considering that no significant changes were observed among the mean values of the three rounds, it is obvious that the respective cobweb diagrams will be similar, as the aggregated mean climate change effects in the three rounds were very close, ranging from EUR 300 to EUR 311.

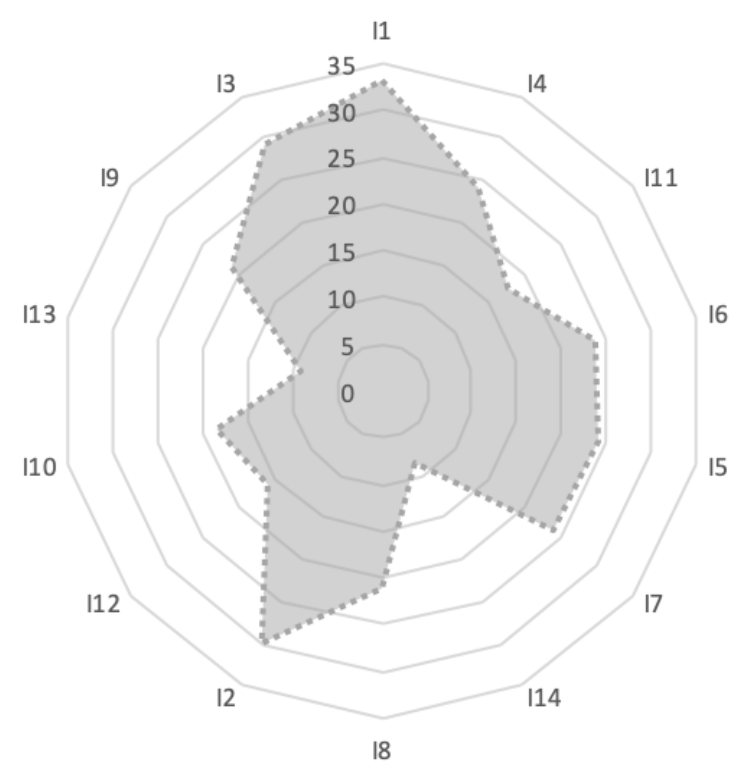

Figure 4. Results of first Delphi round (mean WTP values). 


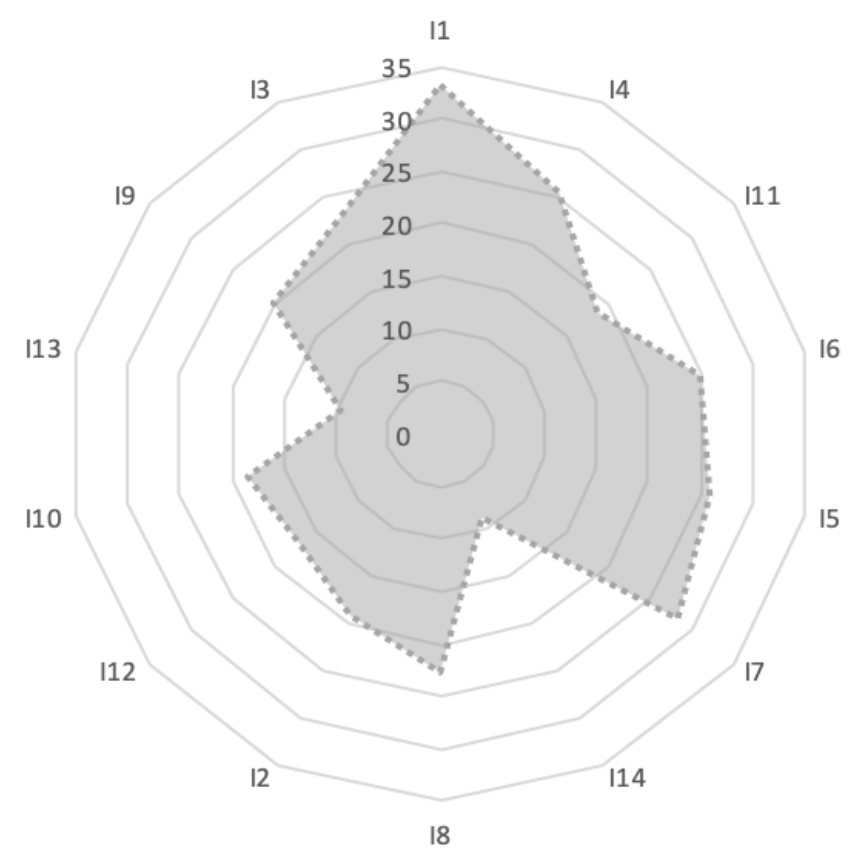

Figure 5. Results of second Delphi round (mean WTP values).

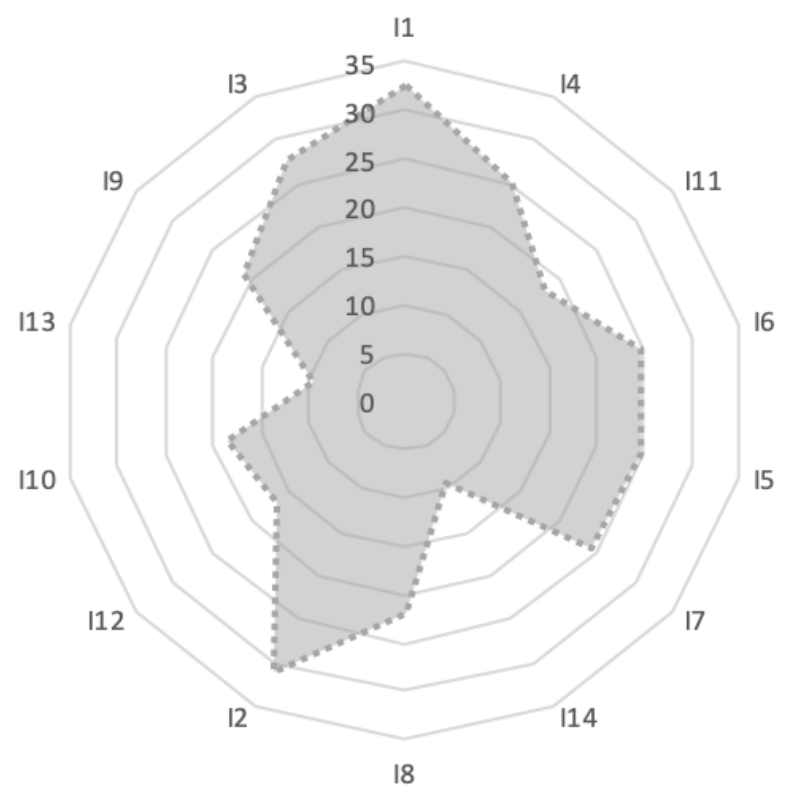

Figure 6. Results of third Delphi round (mean WTP values).

According to the report of Dalkey et al. [24], when selecting experts in a Delphi methodology, we accept that they are more aware of a problem than the rest of the population. Thus, we can adjust the Willingness-To-pay amounts of experts to the whole population. Based on the most recent data (year 2018) of the statistical service of Cyprus, the whole population and the agricultural population of the island were 1,198,575 and 82,040, respectively [42]. When converting the final values of climate change impacts to the national level, the whole cost of climate change for the agricultural population of Cyprus has been estimated at EUR 25.08 million, and for the total population has been estimated at EUR 366.48 million, both on a yearly basis. Based on the expert's viewpoints, among the most important climate change impacts should be considered the "increase of $\mathrm{CO}_{2}$ in the atmosphere" and the "burden of biodiversity and ecosystems". On the other hand, among the less important impacts should be considered the "variability of productivity" and the "diversification of agricultural production and 
agricultural products trade". The following Table 2 presents the conversion of mean estimations to national levels for each climate change impact (for the agricultural and whole populations of the research area).

Table 2. Reduction of the estimations of climate change impacts (EUR).

\begin{tabular}{|c|c|c|c|}
\hline & Impacts of Climate Change & $\begin{array}{c}\text { Reduction to the } \\
\text { Agricultural Population }\end{array}$ & $\begin{array}{l}\text { Reduction to the } \\
\text { Whole Population }\end{array}$ \\
\hline 1. & Increasing of $\mathrm{CO}_{2}$ concentration & $2,679,426$ & $39,145,460$ \\
\hline 2. & $\begin{array}{l}\text { Burden on the environment, ecosystems and of } \\
\text { biodiversity (loss of native species) }\end{array}$ & $2,552,264$ & $37,287,699$ \\
\hline 3. & Increased fire incidents & $2,257,741$ & $32,984,839$ \\
\hline 4. & Warming & $2,051,820$ & $29,976,436$ \\
\hline 5. & Increased occurrence of diseases and pests & $2,020,645$ & $29,521,001$ \\
\hline 6. & Increased frequency of extreme weather events & $2,019,825$ & $29,509,040$ \\
\hline 7. & Intensity of competition in water use in agriculture & $2,002,596$ & $29,257,362$ \\
\hline 8. & $\begin{array}{l}\text { Increased spending on tackling the cost of } \\
\text { irrigation water, appropriate propagation material, } \\
\text { special fertilizers and damage from extreme } \\
\text { weather phenomena }\end{array}$ & $1,804,880$ & $26,368,804$ \\
\hline 9. & Burden of soil fertility and erosion & $1,709,714$ & $24,978,470$ \\
\hline 10. & Increase in price of agricultural products & $1,530,866$ & $22,365,577$ \\
\hline 11. & Variation in rainfall & $1,514,458$ & $22,125,879$ \\
\hline 12. & Reduction of farm income & $1,379,913$ & $20,160,217$ \\
\hline 13. & Change in productivity and yields & 781,021 & $11,410,548$ \\
\hline & $\begin{array}{l}\text { Diversification of agricultural production and } \\
\text { agricultural trade }\end{array}$ & 779,380 & $11,386,586$ \\
\hline & National level & $25,084,550$ & $366,477,917$ \\
\hline
\end{tabular}

\section{Conclusions}

The overall goal of this paper was to investigate climate change issues regarding their impacts on agriculture and water resources in Cyprus. Furthermore, this paper highlights the importance of a mutual understanding among all key stakeholders involved in water resources management and agricultural activity in Cyprus. This paper contributes both methodologically and empirically to the literature by offering a novel context for obtaining quantified and comparative results. Considering that the estimation of the cost of agricultural adaptation to climate change is a very crucial step for designing practical policy measures, any issue related to the quantification of climate change impacts is of great importance. The empirical results of the study confirm the basic argument presented, namely that agricultural activity and irrigation management in Cyprus are both significantly changing as a result of the wider climate change process.

The WTP questions incorporated a very simple discrimination and grouping of climate change impacts. Thus, the numerical EUR value results, concerning avoiding these impacts, must be interpreted with caution and primarily for comparative purposes. The 14 identified impacts of climate change could not be added, as the effect one impact includes some of the other mentioned impacts. The quantification of climate change impacts is only useful to compare the differences, and design policy measures. The summation and reduction of the effects at the national level are completely indicative and aim only at outlining the adaptation cost of Cypriot agriculture to climate change. A second limitation is that what we proposed to measure was not always well measured by the experts. The panel results suggest that some participants were not valuing the climate change impacts based on their expertise but were greatly influenced by the responses of others or by the literature, and generally their WTP may not be representative of the society as a whole. However, the subjective nature of the research problem was not compatible with other more objective valuation approaches. The selection of the methodological 
mix of the research, although it had many disadvantages, extracted some hypothetical results that are important for comparison purposes, and useful for policy proposals. A more exhaustive analysis, using real values, is still an important pending issue in order to shed light on desirable structural changes of Cypriot agriculture, and on the principles and mechanisms that enable these changes. The findings that arose from the described method can provide public authorities with valuable information, that might be used to address issues of sustainability in the water sector and could help to implement strategy in agriculture policy.

Author Contributions: Conceptualization, M.M., S.A.N., D.L., A.S. and K.M.; data curation, G.K. and G.P.; formal analysis, G.P.; investigation, A.M., E.L., D.L. and M.S.A.; methodology, M.M., A.M., E.L., S.A.N., D.L., M.S.A. and G.P.; project administration, M.M., A.S. and K.M.; resources, G.K. and G.P.; software, G.K.; supervision, A.S. and K.M.; validation, M.M.; writing-original draft, A.M., E.L., S.A.N., D.L. and M.S.A.; writing-review \& editing, A.M., E.L., S.A.N., G.K., M.S.A., A.S. and K.M. All authors have read and agreed to the published version of the manuscript.

Funding: This research received no external funding.

Conflicts of Interest: The authors declare no conflict of interest.

\section{References}

1. Hadjinicolaou, P.; Giannakopoulos, C.; Zerefos, C.; Lange, M.A.; Pashiardis, S.; Lelieveld, J. Mid-21st century climate and weather extremes in Cyprus as projected by six regional climate models. Reg. Environ. Chang. 2011, 11, 441-457. [CrossRef]

2. EEA-European Environmental Agency. Water Resources across Europe-Confronting Water Scarcity and Drought; EEA Report No 2/2009; EEA: Copenhagen, Denmark, 2009.

3. Ouma, Y.O.; Tateishi, R. A water index for rapid mapping of shoreline changes of five East African Rift Valley lakes: An empirical analysis using Landsat TM and ETM+ data. Int. J. Remote Sens. 2006, 27, 3153-3181. [CrossRef]

4. Papasozomenou, R.; Zikos, D. Linking perceptions and water management: Reflections from cyprus. Wseas Trans. Environ. Dev. 2009, 5, 749-758.

5. Tsiouris, N.X. Cyprus-Water Resources, Planning and Climate Change Adaptation; Mediterranean Regional Roundtable: Athens, Greece, 2002; pp. 4-21.

6. Alston, M.; Whittenbury, K. Does climatic crisis in Australia's food bowl create a basis for change in agricultural gender relations? Agric. Hum. Values 2013, 30, 115-128. [CrossRef]

7. Moore, A.D.; Ghahramani, A. Climate change and broad-acre livestock production across southern Australia: Adaptation options via livestock genetic improvement. Anim. Prod. Sci. 2014, 54, 111-124. [CrossRef]

8. Nastis, S.A.; Michailidis, A.; Chatzitheodoridis, F. Climate change and agricultural productivity. Afr. J. Agric. Res. 2012, 7, 4885-4893. [CrossRef]

9. World Bank. World Development Indicators: Agricultural Methane Emissions. 2016. Available online: http://data.worldbank.org/indicator/EN.ATM.METH.KT.CE (accessed on 15 January 2020).

10. Kusin, F.M.; Akhir, N.I.M.; Mohamat-Yusuff, F.; Awang, M. The impact of nitrogen fertilizer use on greenhouse gas emissions in an oil palm plantation associated with land use change. Atmosfera 2015, 28, 243-250. [CrossRef]

11. FAO; IFAD; WHO; WFP; UNICEF. The State of Food Security and Nutrition in the World 2019: Safeguarding Against Economic Slowdowns and Downturns; FAO: Rome, Italy, 2019.

12. Smith, P. Agricultural greenhouse gas mitigation potential globally, in Europe and in the UK: What have we learnt in the last 20 years? Glob. Chang. Biol. 2012, 18, 35-43. [CrossRef]

13. Markou, M.; Stylianou, A.; Bruggeman, A.; Zoumides, C.; Pashiardis, S.; Hadjinicolaou, P.; Lange, M.A.; Zachariadis, T.; Michaelides, A. Economic Impact of Climate Change on the Cypriot Agricultural Sector; Working Paper: Nicosia, Cyprus, 2011.

14. Klein, T.; Holzkämper, A.; Calanca, P.; Fuhrer, J. Adaptation options under climate change for multifunctional agriculture: A simulation study for western Switzerland. Reg. Environ. Chang. 2014, 14, 167-184. [CrossRef]

15. Calzadilla, A.; Rehdanz, K.; Betts, R.; Falloon, P.; Wiltshire, A.; Tol, R.S.J. Climate change impacts on global agriculture. Clim. Chang. 2013, 120, 357-374. [CrossRef] 
16. Papadavid, G.; Hadjimitsis, D.; Fedra, K.; Michaelides, S. Smart management and irrigation demand monitoring in Cyprus, using remote sensing and water resources simulation and optimization. Adv. Geosci. 2011, 30, 31-37. [CrossRef]

17. Papadaskalopoulou, C.; Katsou, E.; Valta, K.; Moustakas, K.; Malamis, D.; Dodou, M. Review and assessment of the adaptive capacity of the water sector in Cyprus against climate change impacts on water availability Resources. Conserv. Recycl. 2015, 105, 95-112. [CrossRef]

18. Zachariadis, T. The Costs of Residential Water Scarcity in Cyprus: Impact of Climate Change and Policy Options. Econ. Policy Pap. 2010, 9-10.

19. Thierfelder, C.; Rusinamhodzi, L.; Ngwira, A.R.; Mupangwa, W.; Nyagumbo, I.; Kassie, G.T.; Cairns, J.E. Conservation agriculture in Southern Africa: Advances in knowledge. Renew. Agric. Food Syst. 2015, 30, 328-348. [CrossRef]

20. Lim, K.H.; Hu, W.; Maynard, L.J.; Goddard, E. A Taste for Safer Beef? How Much Does Consumers' Perceived Risk Influence Willingness to Pay for Country-of-Origin Labeled Beef. Agribusiness 2014, 30, 17-30. [CrossRef]

21. Husted, B.W.; Russo, M.V.; Meza, C.E.B.; Tilleman, S.G. An exploratory study of environmental attitudes and the willingness to pay for environmental certification in Mexico. J. Bus. Res. 2014, 67, 891-899. [CrossRef]

22. Nastis, S.A.; Mattas, K. Income elasticity of willingness-to-pay for a carbon tax in Greece. Int. J. Glob. Warm. 2018, 14, 510-524. [CrossRef]

23. Lin, H.I.; Liou, J.L.; Hsu, S.H. Economic Valuation of Public Meteorological Information Services-A Case Study of Agricultural Producers in Taiwan. Atmosphere 2019, 10, 753. [CrossRef]

24. Dalkey, N.C.; Helmer, O. An experimental application of the Delphi method to the use of experts. Manag. Sci. 1963, 9, 458-467. [CrossRef]

25. Hsu, C.C.; Sandford, B.A. The Delphi Technique: Making Sense of Consensus. Pract. Assess. Res. Eval. 2007, $12,1-8$.

26. Linstone, H.A.; Turoff, M. Delphi: A brief look backward and forward. Technol. Forecast. Soc. Chang. 2011, 78, 1712-1719. [CrossRef]

27. Torres, L.; Pina, V. E-participation perspectives. A Delphi study applied to climate change policies. In Proceedings of the IADIS Int. Conf. ICT, Society and Human Beings 2011, Proceedings of the IADIS International Conference e-Democracy, Equity and Social Justice, Part of the IADIS, MCCSIS, Rome, Italy, 20-26 July 2011; p. 19.

28. Doria, M.; Boyd, E.; Tompkins, E.L.; Adger, W.N. Using expert elicitation to define successful adaptation to climate change. Environ. Sci. Policy 2009, 12, 810-819. [CrossRef]

29. Changnon, S.A., Jr. Views of climate change: A Delphi experiment in the Midwest. Bull. Am. Meteorol. Soc. 1982, 63, 1160-1161. [CrossRef]

30. McMillan, S.S.; King, M.; Tully, M.P. How to use the nominal group and Delphi techniques. Int. J. Clin. Pharm. 2016, 38, 655-662. [CrossRef] [PubMed]

31. Okoli, C.; Pawlowski, S.D. The Delphi method as a research tool: An example, design considerations and applications. Inf. Manag. 2004, 42, 15-29. [CrossRef]

32. Schmidt, R.C. Managing Delphi surveys using nonparametric statistical techniques. Decis. Sci. 1997, 28, 763-774. [CrossRef]

33. Hasson, F.; Keeney, S.; McKenna, H. Research guidelines for the Delphi survey technique. J. Adv. Nurs. 2000, 32, 1008-1015.

34. Baker, J.A.; Lovell, K.; Harris, N.; Campbell, M. Multidisciplinary consensus of best practice for pro re nata (PRN) psychotropic medications within acute mental health settings: A Delphi study. J. Psychiatr. Ment. Health Nurs. 2007, 14, 478-484. [CrossRef]

35. Bantel, K. Comprehensiveness of strategic planning: The importance of heterogeneity of a top team. Psychol. Rep. 1993, 73, 35-49. [CrossRef]

36. Boulkedid, R.; Abdoul, H.; Loustau, M.; Sibony, O.; Alberti, C. Using and reporting the Delphi method for selecting healthcare quality indicators: A systematic review. PLoS ONE 2011, 6, e20476. [CrossRef]

37. Delbecq, A.L.; Van de Ven, A.H.; Gustafson, D.H. Group Techniques for Program Planning: A Guide to Nominal Group and Delphi Processes; Scott, Foresman and Company: Glenview, IL, USA, 1975.

38. Lazaridou, D.; Michailidis, A. Valuing users' willingness to pay for improved water quality in the context of the water framework directive. Int. J. Sustain. Dev. World Ecol. 2020, 1-11. [CrossRef] 
39. Lazaridou, D.; Michailidis, A.; Mattas, K. Evaluating the willingness to pay for using recycled water for irrigation. Sustainability 2019, 11, 5220. [CrossRef]

40. Lazaridou, D.; Michailidis, A.; Trigkas, M. Socio-economic factors influencing farmers' willingness to undertake environmental responsibility. Environ. Sci. Pollut. Res. 2019, 26, 14732-14741. [CrossRef] [PubMed]

41. Charatsari, C.; Papadaki-Klavdianou, A.; Michailidis, A.; Partalidou, M. Great expectations? Antecedents of women farmers' willingness to participate in agricultural education programmes. Outlook Agric. 2013, 42, 193-199. [CrossRef]

42. NSSC-National Statistical Service of Cyprus. Analytical Tables. 2020. Available online: https://www.mof.gov.cy/mof/cystat/statistics.nsf/populationcondition_21main_en/populationcondition_ 21main_en?OpenForm\&sub=1\&sel=1 (accessed on 22 April 2020).

(C) 2020 by the authors. Licensee MDPI, Basel, Switzerland. This article is an open access article distributed under the terms and conditions of the Creative Commons Attribution (CC BY) license (http://creativecommons.org/licenses/by/4.0/). 